\title{
Total Synthesis of the Azolemycins
}

\author{
Zoe J. Anderson and David J. Fox †* \\ Received (in $X X X, X X X)$ Xth $X X X X X X X X X 20 X X$, Accepted Xth XXXXXXXXX 20XX \\ DOI: 10.1039/b000000x
}

${ }_{5}$ The first total syntheses of newly isolated polyazole natural products azolemycins A-D, along with the synthesis of the tetra-oxazole non-natural analogue, are described.

\section{Introduction}

Azolemycins A-D are compounds recently isolated from the soil bacterium, Streptomyces sp. FXJ1.264. ${ }^{1}$ A combination of mass 10 spectrometry and $1 \mathrm{D}$ and 2D NMR spectrometry identified the structure as a modified heptapeptide, with four linked azoles and an $N$-terminal oxime. The major isolated azolemycins are the $N$ hydroxy derivative with the greater proportion as the $E$-oxime geometric isomer 1a, named azolemycin A and the lesser 15 proportion as the $Z$ - geometric isomer $\mathbf{1 b}$, named azolemycin $\mathrm{B}$ (Fig. 1). The minor isolated azolemycins differ only in containing an $N$-methoxy group and again were isolated as the $E$-isomer $\mathbf{2 a}$ and the $Z$-isomer $\mathbf{2 b}$ (azolemycins $\mathrm{C}$ and $\mathrm{D}$ respectively).
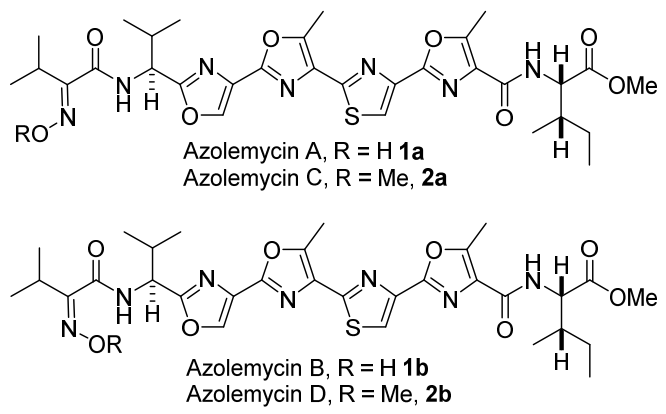

Figure 1 Azolemycins A-D.

The biosynthesis of the azolemycins has been described, ${ }^{1}$ and is believed to involve the posttranslational modification of a ribosomally-biosynthesised 7 amino-acid precursor. The oxime

25 functional group is believed to occur from a previously unknown posttranslational modification, apparently utilizing a flavindependent monooxygenase to catalyse the oxidation of an $\mathrm{N}$ terminal valine residue to the corresponding oxime. ${ }^{1}$ Oximecontaining natural products are unusual, and those reported, 30 including caerulomycin A, althiomycin, collismycin A and nocardicins $\mathrm{A}$ and $\mathrm{B},{ }^{2}$ result from nonribosomal peptide synthesis.

Until the 1980s, very few thiazole and oxazole-containing natural products were known, but an increasing array have since 35 been identified, particularly derived from marine sources. ${ }^{3}$ These products range from single oxazoles and thiazoles to more complicated linked chains or macrocycles of concatenated azoles. The combination of potent biological activity of many of these azole products and the exciting synthetic challenges they pose has 40 made them extremely attractive targets for total syntheses, ${ }^{4}$ and a wide range of reagents have been developed to allow for this. ${ }^{5}$

Polyazoles, or polyazole-containing, natural products made by total synthesis range from the relatively simple linked bis- and triazole motifs, as found in the hennoxazoles, ${ }^{6}$ muscorides, ${ }^{7}$ ${ }_{45}$ bleomycins, ${ }^{8}$ and myxothiazols, ${ }^{9}$ to more complicated macrocyclic molecules such as the heptazole telomestatin, the related YM-216391, IB-01211 and more recently, plantazolicin. ${ }^{10}$ $4 \mathrm{~b}, 11$

\section{Synthetic Strategy}

50 Our chosen disconnection of the azolemycins involved a convergent synthesis, with late stage formation of the central thiazole, similar to the strategy used in the synthesis of YM216391.11a The disconnection gave four distinct units: the isopropyl oxime $\mathbf{3}$, the left-hand mixed bisoxazole fragment $\mathbf{4}$, 55 the right-hand methyl oxazole $\mathbf{5}$ and the isoleucine methyl ester $\mathbf{6}$ (figure 2).

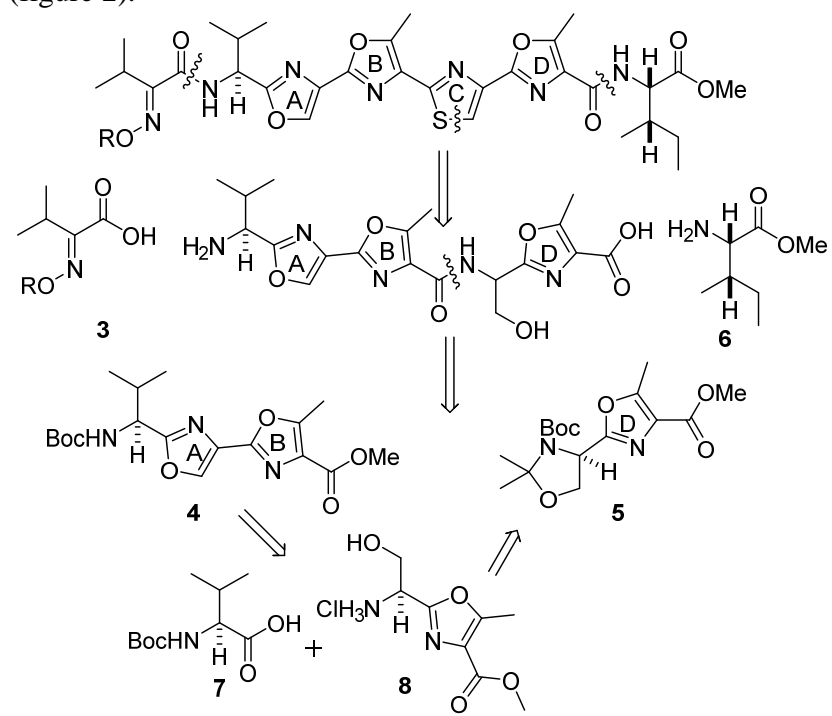

Figure 2 Preliminary disconnections for the synthesis of azolemycin A

60 As we planned to synthesise the thiazole from serine, the tetraazole core could be divided into two repeating serinethreonine dimers, corresponding to a common threonine derived oxazole 5. We therefore further disconnected the $\mathrm{AB}$ unit 4 into oxazole 8 and Boc-L-valine, 7 (figure 2). The protected oxazole 
building block 5 was synthesised from the diprotected Boc-serine acetonide 10. An HOBt/EDCI peptide coupling gave the threonine dipeptide $\mathbf{1 1}$ in excellent yields. Oxidation of the threonine residue using the Parikh-Doering conditions, ${ }^{12}$ and 5 cyclodehydration using $\mathrm{PPh}_{3} / \mathrm{I}_{2} / \mathrm{NEt}_{3}$, as described by Wipf, ${ }^{7 \mathrm{c}}$ gave the oxazole 5 (scheme 1). In some reaction batches some unreacted alcohol 11 was carried through, with ketone 12, to the cyclodehydration step. In these cases, the elimination product $\mathbf{1 3}$ was obtained and this was extremely difficult to separate from 10 oxazole 5. We therefore performed a Sharpless dihydroxylation on the mixture of alkene $\mathbf{1 3}$ and oxazole 5. ${ }^{13}$ This chemoselective procedure did not affect the oxazole but, as predicted, a simple aqueous work-up afforded only the clean oxazole $\mathbf{5}$. We propose that the alkene $\mathbf{1 3}$ formed an unstable diol that decomposed to 15 give two non-isolated water soluble products, an amide and a keto-ester.

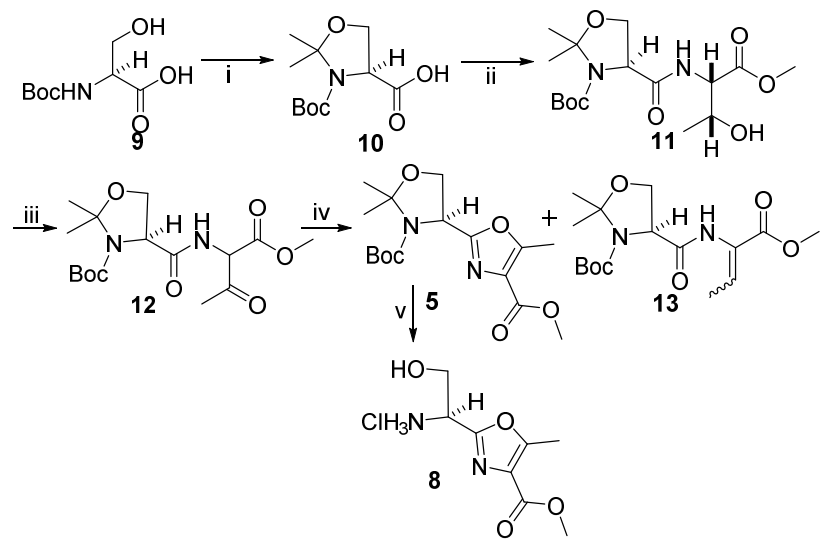

Scheme 1 (i) Dimethoxypropane, TsOH. $\mathrm{H}_{2} \mathrm{O}, \mathrm{CH}_{2} \mathrm{Cl}_{2}, 40{ }^{\circ} \mathrm{C}, 2$ h, $80 \%$; (ii) 1-Thr.OMe.HCl, EDCI, cat. HOBt, EtOH, $0{ }^{\circ} \mathrm{C}$ to rt, 18 h, $84 \%$; (iii) $\mathrm{SO}_{3} . \mathrm{pyr}, \mathrm{DMSO},{ }^{i} \mathrm{Pr}_{2} \mathrm{EtN}, \mathrm{CH}_{2} \mathrm{Cl}_{2}, 0{ }^{\circ} \mathrm{C}, 3 \mathrm{~h}$; (iv) ${ }_{20} \mathrm{PPh}_{3}, \mathrm{I}_{2}, \mathrm{NEt}_{3}, \mathrm{CH}_{2} \mathrm{Cl}_{2}, 0{ }^{\circ} \mathrm{C}$ to rt, $18 \mathrm{~h}, 32 \%$ over 2 steps; (v) $\mathrm{AcCl}, \mathrm{MeOH}, \mathrm{rt}, 18 \mathrm{~h}$, quant

The $\mathrm{AB}$ unit was formed from the tripeptide 14, which was made by coupling Boc-valine $\mathbf{7}$ to the deblocked oxazole-amine $\mathbf{8}$ (scheme 2). The serine residue was then cyclodehydrated using 25 DAST to give the crude oxazoline, as described by Williams et $a l$. in their synthesis of (-)-hennoxazole A. ${ }^{6 a}$. Attempts to oxidise this using standard conditions (e.g. $\mathrm{BrCCl}_{3}$ and $\mathrm{DBU},{ }^{5 \mathrm{f}}$ or $\mathrm{BrCCl}_{3}, \mathrm{CCl}_{4}$ and pyridine ${ }^{14}$ ) were unsuccessful, presumably due to the unactivated nature of the oxazoline. Though oxidations of 30 this type of relatively unactivated oxazoline are not common in the literature, examples do exist which use either $\mathrm{MnO}_{2}$ or $\mathrm{NiO}_{2},{ }^{5 \mathrm{i},}, 11 \mathrm{c}, \quad 11 \mathrm{~d}$ which are assumed to follow a similar mechanism. ${ }^{15}$ Despite being a widely used oxidising agent, many procedures do not state the provenance or preparation method of ${ }_{35} \mathrm{MnO}_{2}$, and the method of preparation has been shown to have a significant effect on the oxidative ability of the reagent. ${ }^{16}$ Yokokawa and Shioiri have reported that chemical manganese dioxide (CMD), manufactured for the production of dry batteries, is a superior oxidising agent than $\mathrm{MnO}_{2}$ prepared by other 40 methods. ${ }^{17} \mathrm{We}$ therefore investigated a method of producing activated $\mathrm{MnO}_{2}$ proposed by Ball, Goodwin and Morton, where an aqueous solution of potassium permanganate is reacted with manganese sulfate in neutral medium to give a precipitate of $\mathrm{MnO}_{2 .}{ }^{18}$ The $\mathrm{MnO}_{2}$ is then activated as required by azeotropic
45 drying with toluene, as described by Goldman. ${ }^{19}$ This provides a source of $\mathrm{MnO}_{2}$ presumably similar in composition to the CMD, and indeed a similar technique using benzene-dried CMD was successfully exploited by Shioiri and Yokokawa for the synthesis of a variety of thiazole-containing natural products. ${ }^{20}$

50 The oxazoline was treated with an excess of the freshly activated $\mathrm{MnO}_{2}$ and, on completion, the residual $\mathrm{MnO}_{2}$ was reduced using aqueous $\mathrm{SO}_{2}$. A simple aqueous work-up and silica chromatography gave the clean bisoxazole 4 in $27 \%$ yield over two steps. It is likely that loss of the $N$-terminal Boc group during 55 the reduction of the $\mathrm{MnO}_{2}$ cause the low yield for this step, and a more resilient protecting group would undoubtedly have improved the yield. As this step provided us with sufficient material to complete the synthesis however, we did not attempt to optimise it further. One major concern was retaining the 60 stereointegrity of the $\mathrm{N}$-terminal valine during oxazole synthesis. Previous work within the group had identified isoleucine as a useful residue to detect epimerization by ${ }^{1} \mathrm{H}$ NMR in similar reactions. Boc-Ile-Ser-OMe was used as a model compound for oxazole, and we were encouraged to see no apparent ${ }_{65}$ epimerization of the $N$-terminal stereocentre (see ESI).

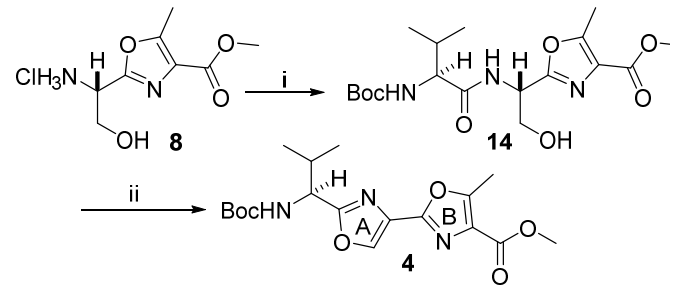

Scheme 2 (i) 7, EDCI, cat. HOBt, NMM, EtOH, rt, 18 h, $88 \%$; (ii) DAST, $\mathrm{CH}_{2} \mathrm{Cl}_{2},-78{ }^{\circ} \mathrm{C}$ to rt $2 \mathrm{~h}$; then $\mathrm{MnO}_{2}$, toluene, $110^{\circ} \mathrm{C}$, $6 \mathrm{~h}, 27 \%$.

70 Methyl ester 4 was hydrolysed, and the resulting acid underwent an EDCI/HOBt coupling with amine 8 to give the pentapeptide, 15. Protection of the pendant alcohol to give $\mathbf{1 6}$ was required to prevent beta-elimination during the formation of the thioamide, which was achieved in excellent yields with 75 Lawesson's reagent to give 17. Deprotection of the alcohol provided 18, which underwent for a further DAST mediated cyclodehydration to give the crude thiazoline. This was oxidised using $\mathrm{CCl}_{4}$ and pyridine to give thiazole 19 in a $27 \%$ yield over 5 steps (scheme 3).

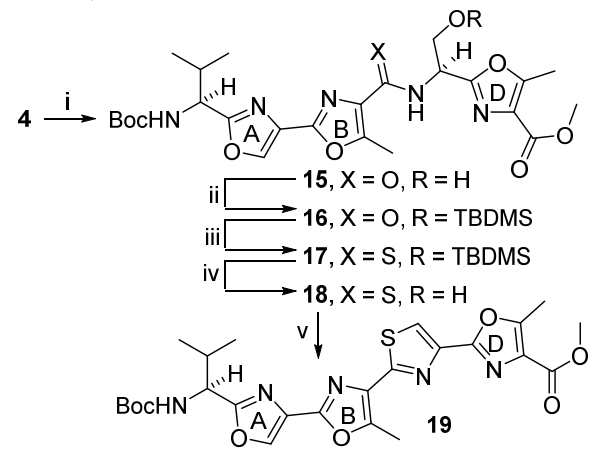

Scheme 3 (i) $\mathrm{LiOH}, \mathrm{H}_{2} \mathrm{O}, \mathrm{THF}, \mathrm{rt}, 4 \mathrm{~h}, 99 \%$; then 8, EDCI, cat. HOBt, NMM, EtOH, rt, 18 h, $73 \%$; (ii) TBDMSCl, imidazole, DMF, $0{ }^{\circ} \mathrm{C}, 3 \mathrm{~h}, 83 \%$; (ii) Lawesson's reagent, toluene, THF, 110 ${ }^{\circ} \mathrm{C}, 44 \mathrm{~h}, 81 \%$; (iii) TBAF, THF, $0{ }^{\circ} \mathrm{C}, 1 \mathrm{~h}, 99 \%$; (iv) DAST, ${ }_{85} \mathrm{CH}_{2} \mathrm{Cl}_{2},-78{ }^{\circ} \mathrm{C}$ to rt $1.5 \mathrm{~h}$; then DBU, pyr., $\mathrm{CCl}_{4}, \mathrm{MeCN}, 0{ }^{\circ} \mathrm{C}$ to rt, $18 \mathrm{~h}, 58 \%$ over 2 steps. 
With the synthesis of the four azoles achieved, the completion of the natural products could be attempted. Saponification of the methyl ester $\mathbf{1 9}$ was more difficult than expected due to its low solubility, but long reaction times, high dilution and a mixture of 5 solvents provided the hydrolysis product $\mathbf{2 0}$, which was readily coupled to isoleucine methyl ester to give the hexapeptide $\mathbf{2 1}$. Removal of the Boc-protecting group allowed coupling 2hydroxy-3-methylbutyric acid 22, made from L-valine according to the method of Bauer and Gajewiak, ${ }^{21}$ to give alcohol 23. This 10 alcohol was oxidised to the ketone $\mathbf{2 4}$ which was reacted with hydroxylamine to give azolemycin A, 1a (scheme 4; 21 steps, 16 steps longest linear sequence, with an overall yield of $0.3 \%$ ). Reaction of ketone $\mathbf{2 4}$ with methoxyamine gave azolemycin D, $\mathbf{2 b}$, with a similar yield.

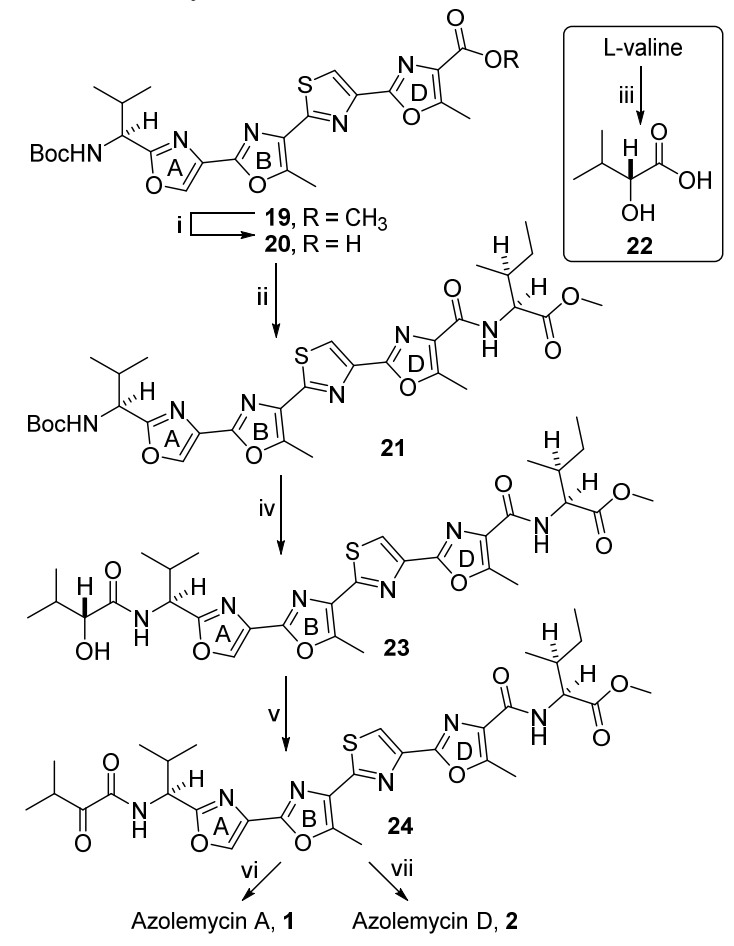

Scheme 4, MeOH, THF, $\mathrm{CH}_{2} \mathrm{Cl}_{2}, \mathrm{H}_{2} \mathrm{O}$, rt, 26 h, $92 \%$; (ii) L-Ile$\mathrm{OMe} . \mathrm{HCl}, \mathrm{EDCI}$, cat. HOBt, NMM, EtOH, rt, 18 h, 84 \%; (iii) $\mathrm{NaNO}_{2}, \mathrm{H}_{2} \mathrm{SO}_{4}, \mathrm{H}_{2} \mathrm{O}, 0{ }^{\circ} \mathrm{C}$ to $\mathrm{rt}, 18 \mathrm{~h}, 31 \%$; (iv)a) $\mathrm{MeOH}$, $\mathrm{AcCl}, \mathrm{rt}, 2 \mathrm{~h}$; b) 22, EDCI, cat. HOBt, NMM, EtOH, $0{ }^{\circ} \mathrm{C}$ to rt, 18 20 h, $90 \%$ over 2 steps; (v) $\mathrm{SO}_{3}$.pyr., $\mathrm{NEt}_{3}$.DMSO, $\mathrm{CH}_{2} \mathrm{Cl}_{2}, 0{ }^{\circ} \mathrm{C}, 3$ h, $65 \%$; (vi) $\mathrm{NH}_{2} \mathrm{OH} . \mathrm{HCl}$, pyridine, $\mathrm{MeOH}, \mathrm{CH}_{2} \mathrm{Cl}_{2}$, rt, 24 h, 58 $\%$; (vii) $\mathrm{NH}_{2} \mathrm{OMe} . \mathrm{HCl}$, pyridine, $\mathrm{MeOH}, \mathrm{CH}_{2} \mathrm{Cl}_{2}, \mathrm{rt}, 4 \mathrm{~h}, 62 \%$.

The ${ }^{1} \mathrm{H}$ NMR spectra of the two synthesized natural products correlate well with the spectra of the naturally derived molecules. ${ }_{25}$ However, while the naturally derived azolemycins were isolated separately as both the $E$ - and $Z$ - oxime isomers, a separation was not possible for the synthesized product, 1 . The synthetic product consisted mainly of the E-oxime 1a (azolemycin A), with only traces of the $Z$-isomer $\mathbf{1 b}$ (azolemycin B), based on the valine $\alpha$ ${ }_{30} \mathrm{CH}$ peaks in ${ }^{1} \mathrm{H}$ NMR spectra. In contrast, the synthetic $N$ methoxy azolemycins, 2, were obtained as primarily the $Z$ geometric oxime isomer (azolemycin $\mathrm{D}$ ), but in $\mathrm{CDCl}_{3}$ showed near complete conversion to the $E$-isomer (azolemycin $\mathrm{C}$ ) in around 5 days.

35 To extend this project, the synthesis of an azolemycin-like tetra-oxazole natural product analogue $\mathbf{3 0}$ was attempted. It was envisaged that any activity shown by the natural product azolemycin A could be compared with this tetraoxazole equivalent to observe the requirement, if any, for the C-ring 40 thiazole. The synthesis of $\mathbf{3 0}$ was achieved in a straightforward fashion by cyclisation and oxidation of serine-derived precursor $\mathbf{1 5}$, forming the $\mathrm{C}$-ring oxazole (scheme 5). This internal oxazole was formed with comparative ease compared to the $N$-terminal oxazole $\mathrm{A}$ in the bisoxazole fragment 4. This supports our 45 hypothesis that, while an adjacent electron withdrawing group at the 4-position is important for the oxidation of oxazolines, the reaction will still proceed in excellent yields if the forming benefits from conjugation at the 2- and 4-positions with neighbouring azoles.

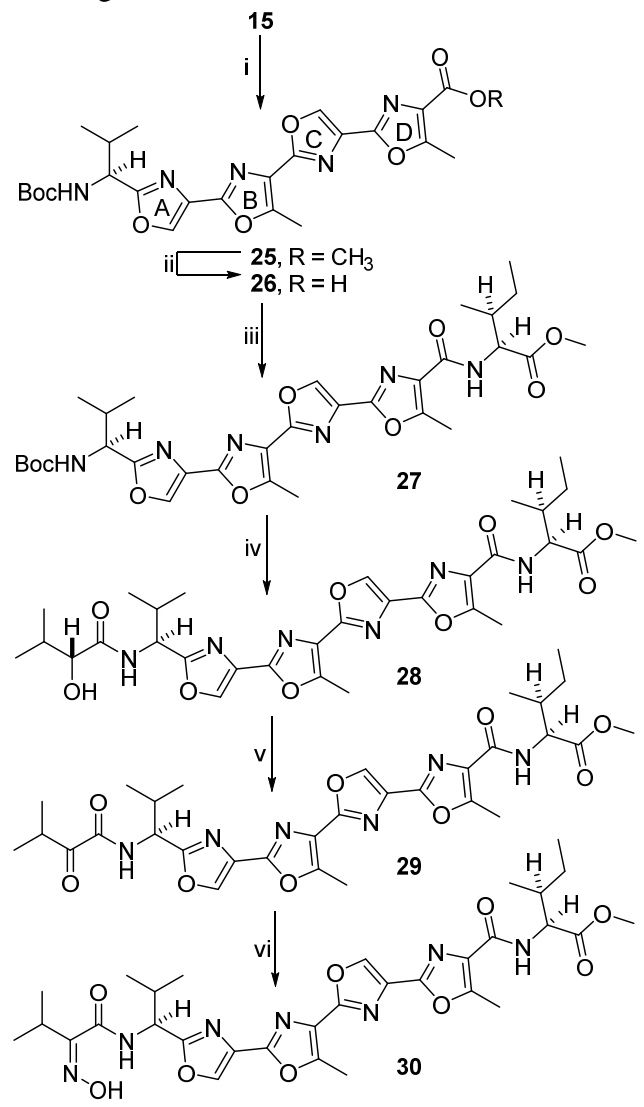

Scheme 5 (i) DAST, $\mathrm{CH}_{2} \mathrm{Cl}_{2}$ then DBU, pyr., $\mathrm{CCl}_{4}, \mathrm{MeCN}, 0{ }^{\circ} \mathrm{C}$ to rt, $72 \mathrm{~h}, 89 \%$; (ii) $\mathrm{LiOH}, \mathrm{H}_{2} \mathrm{O}, \mathrm{THF}, \mathrm{CH}_{2} \mathrm{Cl}_{2}, 67 \%$; (iii) L-IleOMe.HCl, EDCI, cat. HOBt, NMM, EtOH, $0{ }^{\circ} \mathrm{C}$ to rt, $18 \mathrm{~h}, 54$ $\%$; (iv) $\mathrm{MeOH}, \mathrm{AcCl}, \mathrm{rt}, 2 \mathrm{~h}$; then 22, EDCI, cat. HOBt, NMM, ${ }_{55} \mathrm{EtOH}, 0{ }^{\circ} \mathrm{C}$ to rt, $18 \mathrm{~h}, 62 \%$; (v) $\mathrm{SO}_{3}$.pyr., $\mathrm{NEt}$.DMSO, $\mathrm{CH}_{2} \mathrm{Cl}_{2}$, $0{ }^{\circ} \mathrm{C}, 6 \mathrm{~h}, 72 \%$; (vi) $\mathrm{NH}_{2} \mathrm{OH} . \mathrm{HCl}$, pyridine, $\mathrm{MeOH}, \mathrm{CHCl}_{3}$, rt, $18 \mathrm{~h}, 33 \%$.

NMR spectrometry suggests that oxime $\mathbf{3 0}$ was formed as a mixture with the $Z$-isomer as the major isomer, with the major ${ }_{60}$ peak in the $1 \mathrm{H}$ spectrum for the $\mathrm{CH}$ adjacent to the oxime at 3.00 ppm, and the minor peak at $3.49 \mathrm{ppm}$ (compare with $3.50 \mathrm{ppm}$ for $E-\mathbf{1 a}, 3.00 \mathrm{ppm}$ for $Z-\mathbf{1 b})$. Comparison of the ${ }^{13} \mathrm{C} \mathrm{NMR}$ spectra of the tetraoxazole $\mathbf{3 0}$ with the equivalent synthesized azolemycin A 1 showed some distinctive differences. As well as ${ }_{65}$ the obvious shift of the peak corresponding to $C 32$ from 120.2 ppm in $\mathbf{1}$ to $138.31 \mathrm{ppm}$ in $\mathbf{3 0}$, the peaks corresponding to the other carbons of azole $\mathrm{C}$, and those immediately surrounding it, were shifted significantly. In particular, in the thiazole 1 the peak corresponding to B ring carbon $C 11$, occurs at $130.9 \mathrm{ppm}$, but in 
the oxazole $\mathbf{3 0}$ the $C 11$ peak appears at $125.7 \mathrm{ppm}$. This large difference in chemical shift may facilitate the identification of the relative positions of oxazoles and thiazoles in new polyazole natural products.

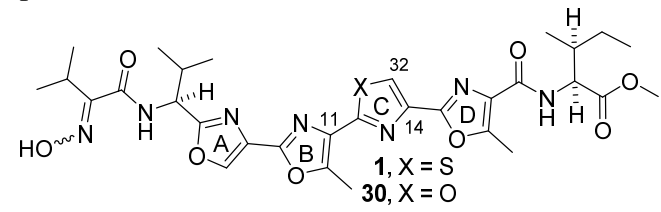

Figure 5 Numbering for azolemycin A, 1 and tetraoxazole 30.

These syntheses produced azolemycin $\mathrm{A}$ and $\mathrm{C}$ and the tetraoxazole analogue 30, for initial biological testing. ${ }^{1} \mathrm{We}$ are continuing assays in this area.

\section{${ }_{10}$ Acknowledgements}

We wish to thank the EPSRC for a DTA studentship (ZJA), Dr Lijiang Song for NMR data for the isolated naturally derived azolemycins and Prof. Greg Challis for useful discussions. Data are available at http://wrap.warwick.ac.uk/74514

\section{Notes and references}

\section{Department of Chemistry, University of Warwick, Gibbet Hill}

Road, Coventry, CV4 7AL, U.K.E-mail: d.j.fox@warwick.ac.uk

$\dagger$ Electronic Supplementary Information (ESI) available: synthesis details and NMR spectra. See DOI: 10.1039/b000000x/

201 N. Liu, L. Song, M. Liu, F. Shang, Z. Anderson, D. J. Fox, G. L. Challis and Y. Huang, Chem. Sci., 2016, Advance Article, DOI: $10.1039 / \mathrm{C} 5 \mathrm{SC} 03021 \mathrm{H}$.

2(a) P. V. Divekar, G. Read and L. C. Vining, Can. J. Chem., 1967, 45, 1215; (b) Y. Y. Kazutoshi Shindo, Yukiko Okada,

25 Hiroyuki Kawai, J. Antibiot., 1994, 47, 1072; (c) D. K. Chatterjee, W. Raether, N. Iyer and B. N. Ganguli, Parasitol. Res., 1984, 70, 569; (d) B. W. Bycroft and R. Pinchin, J. Chem. Soc., Chem. Commun., 1975, 121.

3(a) I. J. Turchi and M. J. S. Dewar, Chem. Rev., 1975, 75, 389; (b) $30 \quad$ I. J. Turchi, Ind. Eng. Chem. Prod. R. D., 1981, 20, 32; (c) J. R. Lewis, Nat. Prod. Rep., 2002, 19, 223; (d) Z. Jin, Z. Li and R. Huang, Nat. Prod. Rep., 2002, 19, 454; (e) Z. Jin, Nat. Prod. Rep., 2013, 30, 869.

4(a) V. S. C. Yeh, Tetrahedron, 2004, 60, 11995; (b) D. 35 Hernández, G. Vilar, E. Riego, L. M. Cañedo, C. Cuevas, F. Albericio and M. Álvarez, Org. Lett., 2007, 9, 809; (c) D. Hernández, E. Riego, F. Albericio and M. Álvarez, Eur. J. Org. Chem., 2008, 2008, 3389; (d) D. A. McGowan, U. Jordis, D. K. Minster and S. M. Hecht, J. Am. Chem. Soc., 1977, 99,

$40 \quad 8078$; (e) B. J. Martin, J. M. Clough, G. Pattenden and I. R. Waldron, Tetrahedron Lett., 1993, 34, 5151; (f) M. G. Banwell and K. J. McRae, J. Org. Chem., 2001, 66, 6768; (g) S. V. Downing, E. Aguilar and A. I. Meyers, J. Org. Chem., 1999, 64, 826; (h) E. Aguilar and A. I. Meyers, Tetrahedron

45 Lett., 1994, 35, 2477; (i) K. C. Nicolaou, B. S. Safina, M. Zak, S. H. Lee, M. Nevalainen, M. Bella, A. A. Estrada, C. Funke, F. J. Zécri and S. Bulat, J. Am. Chem. Soc., 2005, 127, 11159; (j) M. C. Bagley, K. E. Bashford, C. L. Hesketh and C. J. Moody, J. Am. Chem. Soc., 2000, 122, 3301; (k) R. A. Hughes, S. P. Thompson, L. Alcaraz and C. J. Moody, J. Am. Chem. Soc., 2005, 127, 15644; (1) E. Riego, D. Hernández, F. Albericio and M. lvarez, Synthesis, 2005, 2005, 1907.

5(a) R. N. Misra, B. R. Brown, P. M. Sher, M. M. Patel, S. E. Hall, W. C. Han, J. C. Barrish, O. Kocy and D. N. Harris, J. Med. 55 Chem., 1993, 36, 1401; (b) P. Wipf and C. P. Miller, Tetrahedron Lett., 1992, 33, 6267; (c) P. Wipf and C. P. Miller, Tetrahedron Lett., 1992, 33, 907; (d) M. J. Crimmin, P. J. O'Hanlon, N. H. Rogers, F. M. Sime and G. Walker, J. Chem. Soc., Perkin Trans. 1, 1989, 2059; (e) A. J. Phillips, Y.
Uto, P. Wipf, M. J. Reno and D. R. Williams, Org. Lett., 2000 , 2, 1165; (f) D. R. Williams, P. D. Lowder, Y.-G. Gu and D. A. Brooks, Tetrahedron Lett., 1997, 38, 331; (g) J. C. Barrish, J. Singh, S. H. Spergel, W. C. Han, T. P. Kissick, D. R. Kronenthal and R. H. Mueller, J. Org. Chem., 1993, 58, 4494; (h) A. Padwa, J. K. Rasmussen and A. Tremper, J. Am. Chem. Soc., 1976, 98, 2605; (i) D. L. Evans, D. K. Minster, U. Jordis, S. M. Hecht, A. L. Mazzu and A. I. Meyers, J. Org. Chem., 1979, 44, 497; (j) P. Wipf, A. Cunningham, R. L. Rice and J. S. Lazo, Biorg. Med. Chem., 1997, 5, 165; (k) P. Wipf and S. Venkatraman, J. Org. Chem., 1995, 60, 7224; (1) T. Fukuyama and L. Xu, J. Am. Chem. Soc., 1993, 115, 8449; (m) E. Aguilar and A. I. Meyers, Tetrahedron Lett., 1994, 35, 2473.

D. R. Williams, D. A. Brooks and M. A. Berliner, J. Am. Chem. Soc., 1999, 121, 4924; (b) F. Yokokawa, T. Asano and T. Shioiri, Org. Lett., 2000, 2, 4169; (c) E. J. Zylstra, M. W. L. She, W. A. Salamant and J. W. Leahy, Synlett, 2007, 2007, 0623; (d) P. Wipf and S. Lim, J. Am. Chem. Soc., 1995, 117, 558; (e) T. Ichiba, W. Y. Yoshida, P. J. Scheuer, T. Higa and D. G. Gravalos, J. Am. Chem. Soc., 1991, 113, 3173.

P. Wipf and S. Venkatraman, J. Org. Chem., 1996, 61, 6517; (b) A. Nagatsu, H. Kajitani and J. Sakakibara, Tetrahedron Lett., 1995, 36, 4097; (c) P. Wipf and C. P. Miller, J. Org. Chem., 1993, 58, 1575.

H. Umezawa, Prog. Biochem. Pharm., 1976, 11, 18; (b) S. M. Hecht, J. Nat. Prod., 1999, 63, 158.

K. Gerth, H. Irschik, H. Reichenbach and W. Trowitzsch, $J$. Antibiot., 1980, 33, 1474; (b) W. Kohl, B. Witte, G. Höfle, B. Kunze, H. Reichenbach, V. Wray and D. Schomburg, Liebigs Ann. Chem., 1985, 1985, 2088.

J. Linder, T. P. Garner, H. E. L. Williams, M. S. Searle and C. J. Moody, J. Am. Chem. Soc., 2010, 133, 1044; (b) T. Doi, M. Yoshida, K. Shin-ya and T. Takahashi, Org. Lett., 2006, 8, 4165; (c) S. K. Chattopadhyay, S. Biswas and B. K. Pal, Synthesis, 2006, 2006, 1289.

Deeley, A. Bertram and G. Pattenden, Org. Biomol. Chem., 2008, 6, 1994; (b) K.-y. Sohda, M. Hiramoto, K.-i. Suzumura, Y. Takebayashi, K.-i. Suzuki and A. Tanaka, $J$. Antibiot., 2005, 58, 32; (c) Z. E. Wilson, S. Fenner and S. V. Ley, Angew. Chem. Int. Ed., 2015, 54, 1284; (d) S.

Banala, P. Ensle and R. D. Süssmuth, Angew. Chem. Int. Ed., 2013, 52, 9518.

J. R. Parikh and W. v. E. Doering, J. Am. Chem. Soc., 1967, 89, 5505.

K. B. Sharpless, W. Amberg, Y. L. Bennani, G. A. Crispino, J. Hartung, K. S. Jeong, H. L. Kwong, K. Morikawa and Z. M. Wang, J. Org. Chem., 1992, 57, 2768; (b) S. B. King and K. B. Sharpless, Tetrahedron Lett., 1994, 35, 5611.

G. Videnov, D. Kaiser, C. Kempter and G. Jung, Angew. Chem. Int. Edit., 1996, 35, 1503.

L. M. Martin and B.-H. Hu, Tetrahedron Lett., 1999, 40, 7951; (b) G. T. K. Panse, S. K, Indian J. Chem., Sect. B: Org. Chem. Incl. Med. Chem., 1989, 28, 793; (c) S. Nordhoff, S. Bulat, S. Cerezo-Gálvez, O. Hill, B. Hoffmann-Enger, M. López-Canet, C. Rosenbaum, C. Rummey, M. Thiemann, V. G. Matassa, P. J. Edwards and A. Feurer, Bioorg. Med. Chem. Lett., 2009, 19, 6340; (d) D. C. Palmer, The Chemistry of Heterocyclic Compounds, Oxazoles: Synthesis, Reactions, and Spectroscopy, Wiley, 2004.

A. J. Fatiadi, Synthesis, 1976, 1976, 65; (b) S. P. Korshunov and I. V. Leontii, Russ. Chem. Rev., 1966, 35, 942.

T. Aoyama, N. Sonoda, M. Yamauchi, K. Toriyama, M. Anzai, A. Ando and T. Shioiri, Synlett, 1998, 1998, 35.

S. Ball, T. W. Goodwin and R. A. Morton, Biochem. J., 1948 , 42, 516 .

I. M. Goldman, J. Org. Chem., 1969, 34, 1979.

F. Yokokawa, H. Sameshima and T. Shioiri, Synlett, 2001, 2001, 0986; (b) F. Yokokawa, H. Sameshima, T. Shioiri, Tetrahedron Lett., 2001, 42, 4171; (c) H. Sugiyama, F. Yokokawa and T. Shioiri, Org. Lett., 2000, 2, 2149. T. Bauer and J. Gajewiak, Tetrahedron, 2004, 60, 9163. 